\title{
EVOLUTION OF QUATERNARY RIVER TERRACES RELATED TO THE UPLIFT OF THE CENTRAL PART OF THE BOHEMIAN MASSIF
}

\begin{abstract}
B. B a l a t k a, J. K a lv od a: Evolution of Quaternary river terraces related to the uplift of the central part of the Bohemian Massif. - Geografie-Sborník ČGS, 113, 3, pp. 205-222 (2008). - Fluvial sediments in the Vltava, Berounka, Sázava and Labe valleys are preserved as extensive river terrace sequences. These accumulation terraces originated from an interaction of climate-morphogenetic and neotectonic processes in the late Cenozoic. The palaeogeographical history of the central part of the Bohemian Massif is described. Geomorphological analysis of late Cenozoic fluvial sediments preserved in the Bohemian Massif confirm that in total 7 main terrace accumulations with several secondary levels can be differentiated. A chronostratigraphical scheme of erosion and accumulation periods and their relations to variable uplift rates in the late Cenozoic is suggested. The relative height of the oldest fluvial terraces above the present-day bottoms of river valleys is more than $100 \mathrm{~m}$ which indicates the approximate depth of erosion in the Quaternary.
\end{abstract}

KEY WORDS: palaeogeographical history - Quaternary geomorphology - river terraces Bohemian Massif.

The paper was completed in the framework of physical geography themes of the research project of the Faculty of Science, Charles University in Prague, MSM 0021620831 "Geographical systems and risk processes in the context of global changes".

\section{Introduction}

The record of river terraces and related fluvial deposits along the Labe and Vltava rivers in Czechia is traditionally used as the basis for the Quaternary stratigraphy of the region. It is also realised that the terrace system, which is widespread along the major rivers, has developed its form because of uplift of the region. When studying the terrace system and evolution of river valleys, the following procedures have been applied (Balatka, Sládek 1962a, b; Balatka, Loučková 1992; Balatka, Kalvoda 1995): a) evaluation of the existing regional literature, b) analysis of longitudinal profiles of rivers, c) a detailed geomorphological survey of valleys, d) reconstruction of river terraces in both long and transverse valley profiles, e) fitting the established terrace system in the studied valley into the regional terrace system; f) an outline of the main stages of the valley evolution during the Upper Cenozoic. The results of geomorphological research allow one to establish the longitudinal profiles of fluvial terrace accumulations and Neogene sediment localities, the structure of transverse profiles of river valleys and important occurrences of planation surfaces (e.g. Záruba et al. 1977; Tyráček 2001; Tyráček et al. 2004; Balatka, Štěpančíková 2006; Balatka 2007). Moreover, the downvalley profiles 
demonstrate the positions of pronounced valley margins of straight valley reaches.

Problems of late Cenozoic evolution of the Labe valley in Saxony in relation to Neogene sediments, fluvial terraces and deposits of continental glaciations were explored by German authors at the end of the 20th century (e.g. Eissmann 1975, 1995; Wolf 1980). A correlation with the terrace system of the Labe in the Czech territory has also been suggested (Eissmann 1997; Wolf, Schubert 1992; Tyráček et al. 2004). In the same period, attempted comparisons of the river terraces and evolution of valleys in the Bohemian Massif and the Carpathian region was published (Zeman 1974, Balatka 1992). Analysis of the structure of main terrace systems of the eastern margin of the Bohemian Massif and the western part of the Carpathian region indicated the existence of 12 river terraces and levels of fluvial sediments. From these accumulation landforms are 6 higher terraces of Pliocene age (70-120 $\mathrm{m}$ above river level) and the surface of the oldest Quaternary terrace is documented $60 \mathrm{~m}$ above present-day valley bottoms.

In this paper, the main features of the palaeogeographical history of the central part of the Bohamian Massif are presented in relation to global climatic changes and neotectonic processes during the Cenozoic. Sedimentary and morphological records of the evolution of antecedent valleys and river accumulation terraces in the central part of the Bohemian Massif are correlated with regional chronostratigraphical stage divisions of the Quaternary.

\section{Palaeogeographical history of the central part of the Bohemian Massif}

Variscan orogenetic processes shaped the Bohemian Massif as a structurally complicated unit, the central part of which is formed by collisiondeformed and metamorphosed crystalline rocks of the Moldanubicum (Buday et al. 1961, Chlupáč et al. 2002). In the late Permian, the relief of the central part of the Bohemian Massif had the appearance of a post-Hercynian planation surface denuded in a semi-arid and very warm climate. Continental Triassic sediments are of kaolinitic type, which gives evidence of warm and wet climate. The Jurassic sea in the Bohemian Massif was a narrow and shallow strait connecting the German and Carpathian seas. During the Cretaceous, intensive weathering under a humid tropical climate resulted in the origin of a thick tropical mantle of kaolinitic and lateritic regoliths (Demek 2004). The altitude of this planation surface was up to $200 \mathrm{~m}$ above sea level. The post-Hercynian planation surface was covered by kaolinitic and lateritic regoliths and it is situated beneath the Upper Cretaceous sediments of the Bohemian Cretaceous Basin (e.g. Engel, Kalvoda 2002). The uplift of the Bohemian Massif at the end of the Santonian resulted from the ongoing Alpine and Carpathian orogenesis and marked the retreat of the Upper Cretaceous epicontinental sea.

Neotectonic rejuvenation of the Bohemian Massif occurred during the Laramide faulting phase some 65 million years ago. The Bohamian Massif was uplifted and a system of graben structures and diagonal tectono-volcanic zones was formed. At the beginning of the Tertiary, the climate in the Bohemian Massif was humid and tropical, with a mean annual temperature 


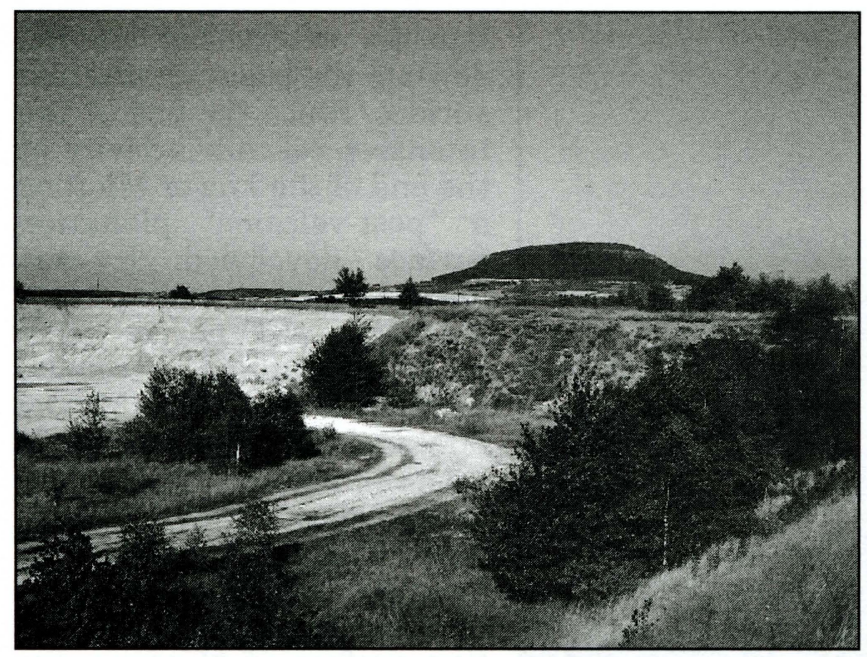

Fig. 1 - Neovolcanic hill of Říp (461 m) is composed by a selectively denuded nephelinitic diatreme. It is surrounded by the Quaternary system of river accumulation terraces in a larger area of the Labe and Vltava revers confluence. Photo B. Balatka.

This is evidenced by duricrust relics in western and central Bohemia (Demek 2004). At the end of the Oligocene, planation of the relief of the Bohemian Massif was interrupted by tectonic movements (e.g. Malkovský 1979, Ivan 1999, Chlupáč et al. 2002), accompanied in its western and northwestern part by volcanic activity $35-17$ million years ago (Fig. 1 ).

The initial impulse towards the morphographical distinctiveness of geomorphological units was given in the Lower Miocene (Aquitanian to Burdigalian), when tectonic disintegration of the planation surface occurred. The granular character of some fluvial and lacustrine sediments from that time shows that certain morphostructural units were already quite distinctive. The progressive subsidence of the southern and southeastern parts of the Bohemian Massif in the Middle Miocene enabled the sea to penetrate into these regions (Malkovský 1975, 1979). Depressions in the region of the Ohře rift and differential movements of the main fault zones in the Bohemian Massif were also morphotectonically significant. Moreover, the evolution of the relief of the Bohemian Massif was influenced by two neotectonic stages of volcanic activity in the late Miocene (between 9.0 and 6.4 Ma) and from the late Pliocene to the Pleistocene (between 3.0 and $0.17 \mathrm{Ma}$, Wagner et al. 1998). The granular character of Pliocene river sediments is similar to those of Lower Pleistocene terrace deposits which indicates that the orographic situation of the Bohemian Massif was roughly similar to that of today (Balatka 2006; Kalvoda, Balatka 2006). Neotectonic movements (mainly uplifts) and erosional-denudational processes in the Quaternary only emphasized the morphographical features of geomorphological units.

During the early Miocene, a tropical humid climate with dry periods prevailed in the Bohemian Massif, which later changed to a subtropical wet climate in the late Miocene. Periods of humid climate in the Neogene were characterised by very extensive erosion and denudation of the kaolinitic and 


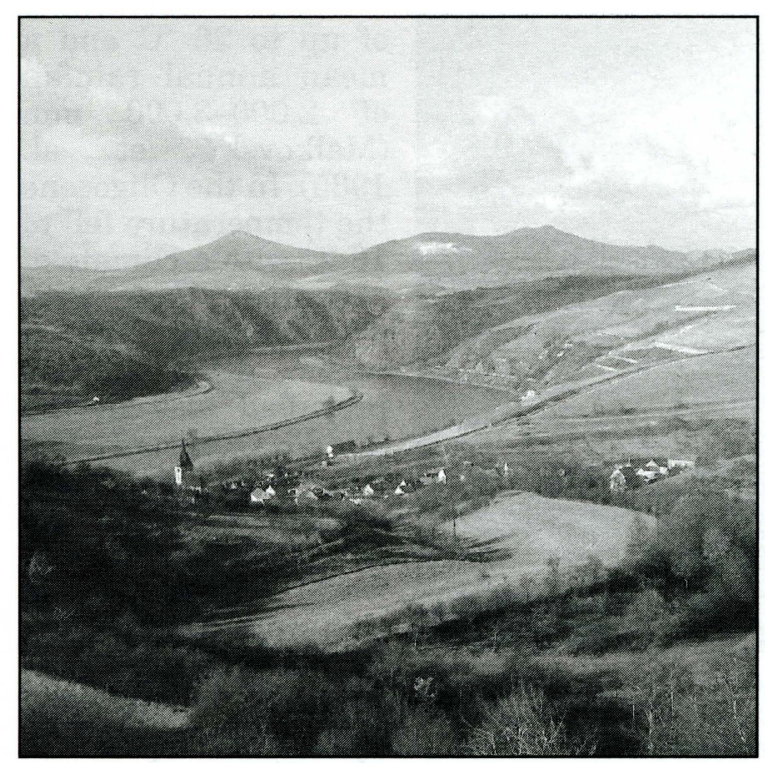

Fig. 2 - Antecedent valley of the Labe river near Litomerrice town is cut through an uplifted horst of crystalline rocks which is an underlier of neovolcanic rocks in the České středohoří Low mountain range. Photo B. Balatka.

lateritic weathering mantle, down to the basal weathering surface. Since the end of the intensive volcanic activity at the end of the Lower Miocene a "post-volcanic" planation surface developed. It was formed under warm, permanently wet or, in some seasons, humid climatic conditions from the Middle Miocene, through the whole Pliocene period (5.3-2.6 Ma) to the lowest Early Pleistocene. The morphostructural features and the internal differentiation of this planation surface of Neogene age were dependent on the rock resistance to weathering under a tropical or subtropical climate.

In the Oligocene and the Miocene, the main European watershed between the epicontinental sea in the north-west and the basins of the Para-Tethys in the south-east crossed the Bohemian Massif approximately along the north-western margin of the central Bohemian pluton, then turned to the northern part of the Českomoravská vrchovina Highlands, and from there it continued to the north (Chlupáč et al. 2002). The oldest indications of the disposition and changes of the river network of the Bohemian Massif are preserved in the sedimentary record of the Miocene. In the Middle and late Miocene, southern Bohemia was still drained to the south, which is corroborated by both relics of fluvial and lacustrine sediments and secondary finds of river-transported moldavites in the adjacent part of Austria. The period of their impact is radiometrically dated as 14.3 million years. In the late Cenozoic, the regionally differentiated tectonic uplift and changes of the European climate are the evolution of the fluvial network of the Bohemian Massif. Important changes in its overall system occurred with significant manifestations of epigenetic and antecedent evolution of river valleys (Fig. 2) through deep, lateral and headward erosion, as well as related reconstruction of the large area of fluvial sedimentation.

\section{River terraces related to uplift of the Central Bohemia during the Quaternary}

The reconstruction method adapted in characterising the terrace system was based on the assumption that the main terrace elements, i.e. the baselevel and the topographic surface, form stable gradients of their long profiles 
Tab. 1 - Chronostratigraphical correlation of river terraces in the central part of the Bohemian Massif related to North West Europe stratigraphical stages of the Quaternary

\begin{tabular}{|c|c|c|c|c|c|}
\hline $\begin{array}{l}\text { Regional stratigraphical } \\
\text { stage/substage divisions } \\
\text { of the Quaternary } \\
\text { (Gibbard et al. 2004) }\end{array}$ & $\begin{array}{l}\text { SÁZAVA } \\
\text { Balatka, } \\
\text { Štěpančíková, } \\
\text { (2006); Balatka } \\
(2007) ; \text { Kalvoda } \\
(2007 a)\end{array}$ & $\begin{array}{l}\text { BEROUNKA } \\
\text { Balatka, } \\
\text { Loučková } \\
\text { (1992) }\end{array}$ & $\begin{array}{l}\text { VLTAVA - LABE } \\
\text { confluence area } \\
\text { Balatka, Sládek } \\
\text { (1962) }\end{array}$ & $\begin{array}{l}\text { VLTAVA } \\
\text { Záruba et } \\
\text { al. (1977) }\end{array}$ & $\begin{array}{l}\text { VLTAVA and } \\
\text { LABE system } \\
\text { Tyráček (2001), } \\
\text { Tyráček et al. } \\
\text { (2004) }\end{array}$ \\
\hline $\begin{array}{l}\text { Late Pleistocene } \\
\text { Weichselian }\end{array}$ & $\begin{array}{l}\text { Pikovice Terrace } \\
\text { (VII) }\end{array}$ & $\begin{array}{l}\text { Lipence } \\
\text { Terrace (VIIa) } \\
\text { Dobřichovice } \\
\text { Terrace (VIIb) }\end{array}$ & $\begin{array}{l}\text { Hostín Terrace } \\
\text { (VIIa, b, c, d) }\end{array}$ & $\begin{array}{l}\text { Maniny } \\
\text { Terrace } \\
\text { (VII) }\end{array}$ & $\begin{array}{l}\text { Maniny Terrace } \\
\text { (Weichselian) } \\
\text { Hostín 1 } \\
\text { Terrace }\end{array}$ \\
\hline $\begin{array}{l}\text { Middle Pleistocene } \\
\text { Saalian (Warthe) }\end{array}$ & $\begin{array}{l}\text { Poříćí } \\
\text { Terrace (VI) }\end{array}$ & $\begin{array}{l}\text { Kazín } \\
\text { Terrace(VI) }\end{array}$ & $\begin{array}{l}\text { Mlčechvosty } \\
\text { Terrace (VIa, b, c) }\end{array}$ & $\begin{array}{l}\text { Veltrusy } \\
\text { Terrace } \\
\text { (VI) }\end{array}$ & $\begin{array}{l}\text { Veltrusy } \\
\text { Terrace } \\
\text { (Warthe) }\end{array}$ \\
\hline $\begin{array}{l}\text { Middle Pleistocene } \\
\text { Saalian (Drenthe) }\end{array}$ & $\begin{array}{l}\text { Městečko } \\
\text { Terrace }(\mathrm{V})\end{array}$ & $\begin{array}{l}\text { Liblín } \\
\text { Terrace (Va) } \\
\text { Poučník } \\
\text { Terrace }(\mathrm{Vb})\end{array}$ & $\begin{array}{l}\text { Cítov Terrace } \\
(\mathrm{Va}, \mathrm{Vb})\end{array}$ & $\begin{array}{l}\text { Dejvice } \\
\text { Terrace } \\
\text { (V) }\end{array}$ & $\begin{array}{l}\text { Dejvice } 1 \text { and } 2 \\
\text { Terrace } \\
\text { (Drenthe) }\end{array}$ \\
\hline $\begin{array}{l}\text { Middle Pleistocene } \\
\text { Saalian (Fuhne) }\end{array}$ & $\begin{array}{l}\text { Týnec } \\
\text { Terrace (IV) }\end{array}$ & $\begin{array}{l}\text { Zbraslav } \\
\text { Terrace (IVa) } \\
\text { Hýskov } \\
\text { Terrace (IVb) }\end{array}$ & $\begin{array}{l}\text { Hněvice Hill } \\
\text { Terrace (IV) }\end{array}$ & $\begin{array}{l}\text { Letná } \\
\text { Terrace } \\
\text { (IV) }\end{array}$ & $\begin{array}{l}\text { Letná Terrace } \\
\text { (Fuhne) }\end{array}$ \\
\hline $\begin{array}{l}\text { Middle Pleistocene } \\
\text { Elsterian }\end{array}$ & $\begin{array}{l}\text { Buda Terrace } \\
\text { (IIIb) }\end{array}$ & $\begin{array}{l}\text { Srbsko } \\
\text { Terrace (IIIb) }\end{array}$ & (IIIb) & $\begin{array}{l}\text { Vinohrady } \\
\text { Terrace } \\
\text { (IIIB) }\end{array}$ & $\begin{array}{l}\text { Vinohrady } \\
\text { Terrace (Elster) }\end{array}$ \\
\hline $\begin{array}{l}\text { Middle Pleistocene } \\
\text { Cromerian complex } \\
\text { (Glacial c) }\end{array}$ & $\begin{array}{l}\text { Chabeřice } \\
\text { Terrace (IIIa) }\end{array}$ & $\begin{array}{l}\text { Tetín } \\
\text { Terrace (IIIa) }\end{array}$ & $\begin{array}{l}\text { Straškov Terrace } \\
\text { (IIIa) }\end{array}$ & $\begin{array}{l}\text { Kralupy } \\
\text { Terrace } \\
\text { (IIIA) }\end{array}$ & $\begin{array}{l}\text { Kralupy } \\
\text { Terrace } \\
\text { (Cromerian C) }\end{array}$ \\
\hline $\begin{array}{l}\text { Middle Pleistocene } \\
\text { Cromerian complex } \\
\text { (Glacial c) }\end{array}$ & $\begin{array}{l}\text { Český Šternberk } \\
\text { Terrace(II) }\end{array}$ & $\begin{array}{l}\text { Pohořelec } \\
\text { Terrace (IIa) } \\
\text { Hlince Terrace } \\
\text { (IIb) }\end{array}$ & Ledčice Terrace (II) & $\begin{array}{l}\text { Pankrác } \\
\text { Terrace } \\
\text { (II) }\end{array}$ & $\begin{array}{l}\text { Pankrác } \\
\text { Terrace } \\
\text { (Cromerian C) }\end{array}$ \\
\hline $\begin{array}{l}\text { Middle Pleistocene } \\
\text { Cromerian complex } \\
\text { (Glacial b) }\end{array}$ & $\begin{array}{l}\text { Hvězdonice } \\
\text { Terrace (Ib) }\end{array}$ & $\begin{array}{l}\text { Řevnice } \\
\text { Terrace (Ib) }\end{array}$ & & $\begin{array}{l}\text { Suchdol } \\
\text { Terrace } \\
\text { (IB) }\end{array}$ & $\begin{array}{l}\text { Suchdol Terrace } \\
\text { (Cromerian B) }\end{array}$ \\
\hline $\begin{array}{l}\text { Middle Pleistocene } \\
\text { Cromerian complex } \\
\text { (Glacial a) }\end{array}$ & $\begin{array}{l}\text { Střechov } \\
\text { Terrace (Ia) }\end{array}$ & $\begin{array}{l}\text { Skryje } \\
\text { Terrace (Ia) }\end{array}$ & Krabčice Terrace (I) & $\begin{array}{l}\text { Lysolaje } \\
\text { Terrace } \\
\text { (IA) }\end{array}$ & $\begin{array}{l}\text { Lysolaje } \\
\text { Terrace } \\
\text { (Cromerian A) }\end{array}$ \\
\hline $\begin{array}{l}\text { Early Pleistocene } \\
\text { Bavelian (Dorst) } \\
\text { Menapian }\end{array}$ & & & Rovné Terrace & & $\begin{array}{l}\text { Rovné } \\
\text { Terrace (Dorst) } \\
\text { Vráž Terrace } \\
\text { (Menapian) }\end{array}$ \\
\hline $\begin{array}{l}\text { Early Pleistocene } \\
\text { Eburonian - Menapian }\end{array}$ & $\begin{array}{l}\text { Niveau B } \\
\text { Radvanice }\end{array}$ & Niveau B & & $\begin{array}{l}\text { Zdiby } \\
\text { Stadium } \\
\text { (Pliocene) }\end{array}$ & $\begin{array}{l}\text { Zdiby Terrace } \\
\text { (Eburonian - } \\
\text { Menapian) }\end{array}$ \\
\hline $\begin{array}{l}\text { Early Pleistocene } \\
\text { Tiglian }\end{array}$ & & & & & $\begin{array}{l}\text { Střibrníky } \\
\text { Terrace (upper } \\
\text { Tiglian) }\end{array}$ \\
\hline Neogene & $\begin{array}{l}\text { Niveau A } \\
\text { Bojiště }\end{array}$ & Niveau A & & $\begin{array}{l}\text { Klínec } \\
\text { Stadium }\end{array}$ & \\
\hline
\end{tabular}


corresponding to the so-called equilibrium profile. Under these conditions, the mean water volume of the stream is in equilibrium with its transportation capacity and the river neither erodes nor accumulates sediment but applies all its energy to the transfer of transported material (Novák 1932; Krejčí 1939; Záruba-Pfeffermann 1942; Záruba et al. 1977). The equilibrium state may be disturbed by differentiated tectonic movements and discharge oscillation, also by an increased quantity of transported matter brought to the river by intensive cryogenic processes during the Pleistocene. Then a huge accumulation (so-called "climatic aggradation") occurred and the channel occupied a new equilibrated profile. Formation of huge aggradations was largely influenced by marked steps in the gradient of the stream; these represent the front of backward erosion which proceeded upstream during the valley downcutting phase. They also represent places reached by the accumulation stage of the respective terrace.

The oldest river terrace accumulations in central Bohemia are situated above the margins of the canyon-like valleys of the Vltava, Berounka and Sázava Rivers (e.g. Záruba et al. 1977, Kovanda et al. 2001). Relics of Miocene gravels and sands at the Sulava locality, near Radotín town have their surface lowered by erosion at $358 \mathrm{~m}$ a. s. l. and their base at $314 \mathrm{~m}$ a. s. l., i.e. $163 \mathrm{~m}$ or $119 \mathrm{~m}$ above the Berounka level. Other relics of these sediments of Miocene and Pliocene ages are recorded from the neighbourhood of Slivenec, near Suchomasty and on Bílá Hora $(380 \mathrm{~m}$ a. s. 1.). The surface of Early Pleistocene sands and gravels up to $40 \mathrm{~m}$ thick, between Kobylisy and Sedlec on the Zdibská plošina Plateau, is situated at 300 to $325 \mathrm{~m}$ a. s. l., i.e. 125 to $150 \mathrm{~m}$ above the Vltava level, and 35-60 $\mathrm{m}$ below the Ládví touchstone ridge (359 $\mathrm{m}$ a. s. 1.). Northwards from these Pliocene spreads on the Zdibská plošina Plateau, up to $20 \mathrm{~m}$ thick sediments (with their surface $112 \mathrm{~m}$ above the Vltava level) are present, dating, within the so-called Lysolaje group of terraces, from the Pleistocene (for stratigraphical positions see Tab. 1). They also include rounded pebbles and boulders of crystalline rocks from the regions of Kutná Hora, Ríčany and Kouřim towns (Záruba-Pfeffermann 1941).

In the Early Pleistocene, the Vltava and its affluents were still freely meandering in shallow and large valleys formed on Neogene planation surfaces. Even as late as in the Middle Pleistocene, the lower limit of which is the Matuyama / Brunhes palaeomagnetic boundary 780,000 years ago, new terrace steps were being progressively formed (70 to $100 \mathrm{~m}$ above the present water courses) together with a relatively rapid epigenetic and antecedent deepening of the river network. For example, the Suchdol Terrace is situated up to $2 \mathrm{~km}$ west of, and $96 \mathrm{~m}$ above the Vltava valley (Tab. 1).

The Straškov (IIIb) Terrace of Balatka, Sládek (1962a, b) is now ca $70 \mathrm{~m}$ above the Vltava river near Račiněves in the neighbourhood of Říp mountain. It is described by Tyráček (2001) as the Straškov 2 Terrace and as an equivalent of the Vinohrady Terrace in Prague (Tab. 1). During aggradation of the Straškov 2 Terrace, the Vltava flowed west of the Oligocene - Miocene volcanic neck of Ríp, subsequently diverting to its present-day position east of Ríp. The fluvial deposits of the Straškov Terrace are comprised of a coarse lower unit and a finer upper unit (Tyráček et al. 2004). It is overlain by loess and slope deposits that include palaeosols representing probably two warm stages. The 12-14 m thick lower fluvial units with stratified sands and gravels indicate a cold-climate braided-channel environment. The $0.5-2 \mathrm{~m}$ thick upper fluvial unit is composed of sand and fine sandy gravel, disturbed by cryoturbation. It has yielded thermophilous mammals, interglacial 


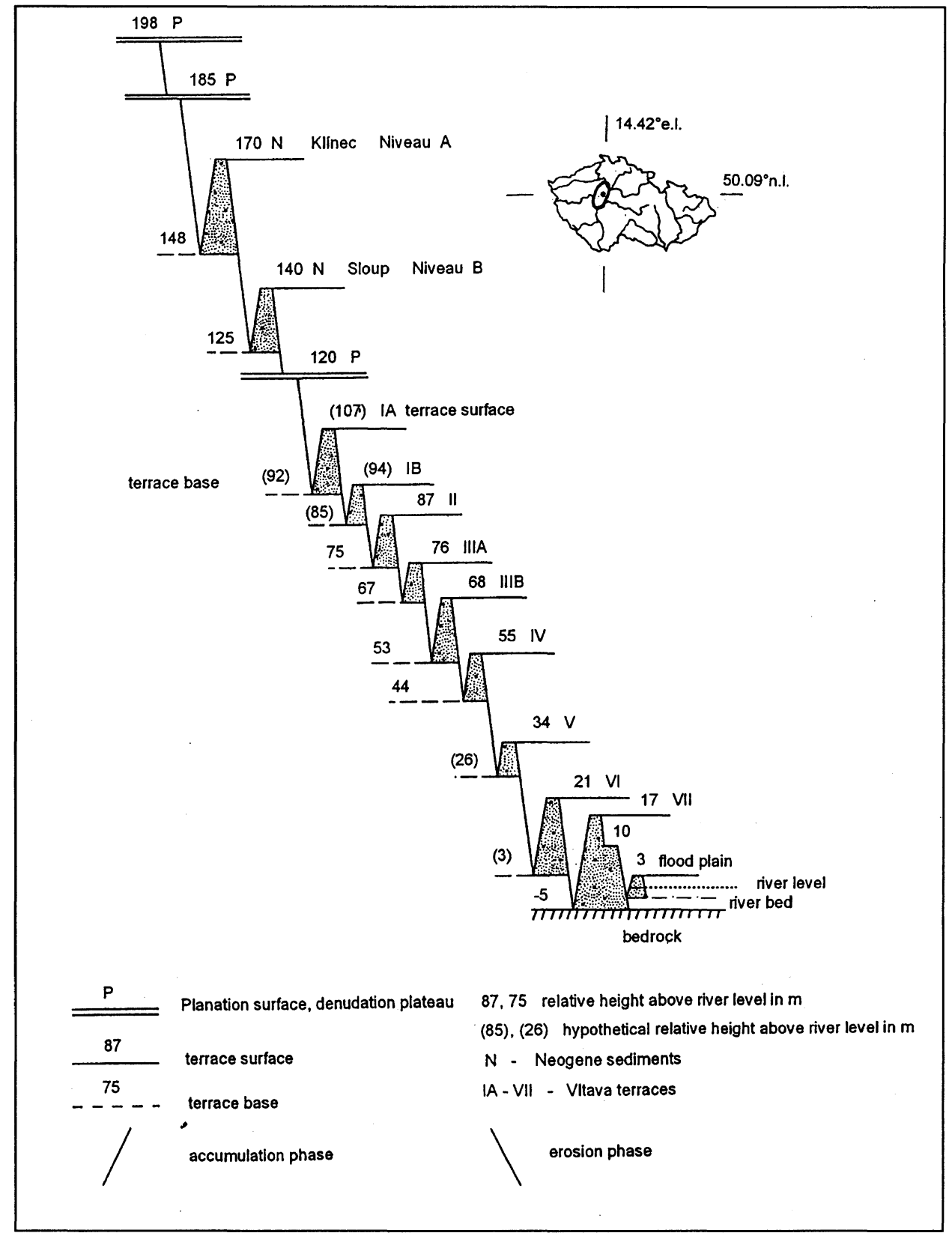

Fig. 3 - Position of river accumulation terraces in the Vltava valley between mounths of the Sázava and Berounka rivers (adapted from Balatka, Štěpančíková 2006 and Balatka 2007). Stratigraphical correlation of accumulation terraces are demonstrated in Table 1.

molluscs and archaeological material.

The Vltava terrace sequence (Fig. 3) can be subdivided longitudinally into two reaches. Downstream of its confluence with the Sázava river the terraces are subparalled to each other and to the modern channel gradient of ca 


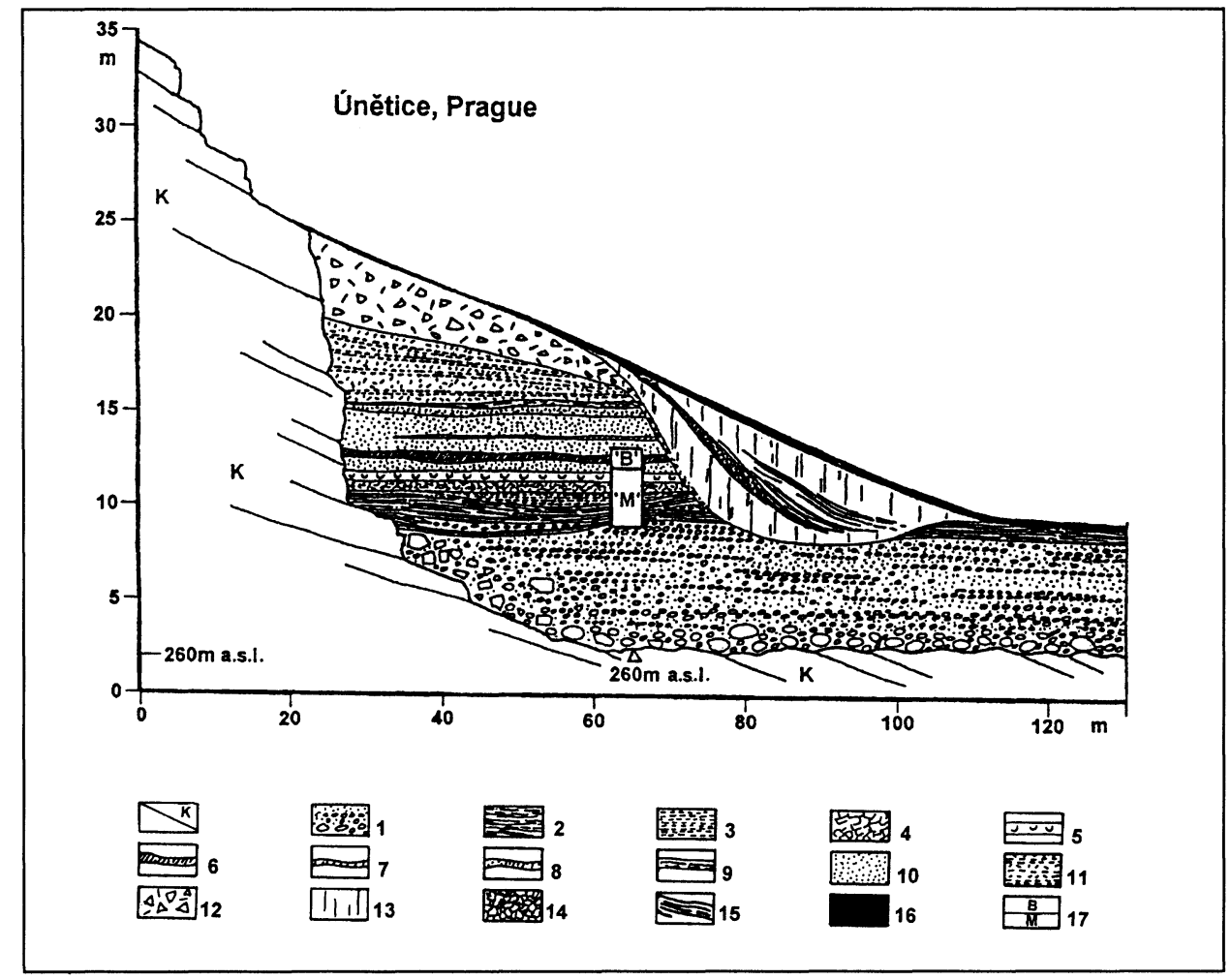

Fig. 4 - Cross-section through the Suchdol Terrace of the Vltava river (near Únětice) of the Pleistoce age (adapted from Záruba et al. 1977 and Tyráček et al. 2004). Explanations: K Proterozoic lydite, 1 - gravel of the Suchdol Terrace, 2 - floodplain clay, 3 - calcareous channel deposits, 4 - brown decalcified floodplain soil, 5 - grey freshwater marl, 6 - dark humic gley soil intercalation, 7 - rusty brown gley soil intercalation, 8 - slopewash derived from Cretaceous sandy limestones, 9 - clayey slopewash, 10 - loose calcareous tufa, 11 slopewash containing Cretaceous debris, 12 - debris of Proterozoic lydite, 13 - loess, 14 parabraunerde soil, 15 - reworked older chernozem, 16 - post-glacial chernozem soil, 17 possible magnetostratigraphical boundary of Matuyama and Brunhes chrons (after interpretation by Záruba et al. 1977).

$0.4 \mathrm{~m} . \mathrm{km}-1$. Further upstream, the channel gradient is more variable, but typically steeper than the terraces, which thus converge towards the source of the river (Balatka, Sládek 1962a). An estimation of the values of the antecedent deepening of the Vltava river according to the position of relics of river accumulation terraces is influenced by a series of uncertainties such as terrace surfaces being irregularly lowered by erosion (comp. Fig. 4) and destruction of their base. However, the results of the estimation are an example of the dynamics of fluvial incision into bedrock and the transportation of weathered material in the region of central Bohemia during the Quaternary (Kalvoda, Balatka 2006): a) Middle Miocene to Pliocene: rate of deepening about $2-4 \mathrm{~cm} / 1,000$ years, b) Early Pleistocene: 6-12 cm/1,000 years, c) the younger part of the Middle Pleistocene: 6-8 cm/100 years, d) a part of the Late Pleistocene (40 to $20 \mathrm{ka})$ : 2-4 cm/1,000 years, e) Holocene: mostly recycling of gravels, sands and slope accumulations in the valley bottom. The rate of downward erosion of the 
Vltava probably reached its maximum of between 6 and $10 \mathrm{~cm} / 100$ years at some time during the Middle Pleistocene (Kalvoda, Balatka 2006; Kalvoda $2007 a, b)$.

The deepening of the river network in the late Cenozoic is also indicated by landform evolution in the area of the regional base level of erosion of the Bohemian Massif (respectively of the Česká vysočina Highlands), i.e. in the Děčínská vrchovina Hilly Land. Between Děčín and Hřensko, erosion by the river Labe reached at least $50 \mathrm{~m}$ in the Pliocene and $180-200 \mathrm{~m}$ in the Quaternary (Balatka, Kalvoda 1995; Kalvoda, Balatka 1995; Kalvoda et al. 2004). Besides the system of river accumulation terraces, wind-blown sands, loess loams and loess (e.g. Demek et al. 1965, Czudek 1997) provide valuable sedimentary evidence of the evolution of landforms in the Quaternary (Figures 1 and 4). They have survived in a stratigraphically significant thickness in depressions or on lower plateaux of the Česká vysočina Highlands.

A very important secular process related to the dynamics of fluvial events in the Quaternary is the oscillation of the surface of oceans due to climatic changes. An example from the Late Pleistocene of the recent geodynamics of the European area may be the difference of levels of the world ocean between the Eemian interglacial stage and the Vistulan glacial. In the Eemian (130,000-116,000 years ago), the ocean flooded the English Channel and, on the contrary in the Vistula glacial $(60,000-13,000$ years ago), when the Scandinavian continental ice sheet moved to the Berlin region 28,000 years ago, the level of the world ocean was about $120 \mathrm{~m}$ lower than it is today.

\section{Sázava valley evolution: an example of the interaction of neotectonics and climate changes during the late Cenozoic}

The Sázava valley was formed by integration of several Miocene individual catchment areas with different drainage directions accomplished by captures. According to Novák (1932), these were the western part of the upper course orientated from Světlá nad Sázavou northwards in the direction of the today's Sázavka, Želivka and Blanice rivers directed as individual streams to the middle Labe region and to the lower course basin either northwards or westwards to Klínec and lower Berounka (Malkovský 1975).

The genesis and structure of the terrace system and valley evolution within the $225 \mathrm{~km}$ longitudinal profile of the stream was largely influenced by two marked steps (bends) of increased water surface incline (Figures 5 and 6): the upper one in the Melechov granite massif (between the river kilometres 139.5 and 135.4) and the lower one (river kilometres 18-5). While in these reaches the mean gradient is $5.7 \%$ and $3.9 \%$ respectively, the $108 \mathrm{~km}$ long reach between two steps shows a mean gradient of only $0.88 \%$ (Balatka 2007). The incline in the reach upstream of the Melechov step is also constant (between river $\mathrm{km} \mathrm{168-135} \mathrm{in} \mathrm{average} 1.3 \%$ ). This upstream reach is situated in a hanging position (approximately $25 \mathrm{~m}$ ) above the valley bottom of the middle course.

Daneš (1913) introduced the concept of a Central Bohemian Oligocene peneplain and suggested the possibility of drainage of the middle Sázava to the north, in the direction of Kouřim. The fundamental paper on terraces and both valley and catchment evolution is the monograph by Novák (1932), 


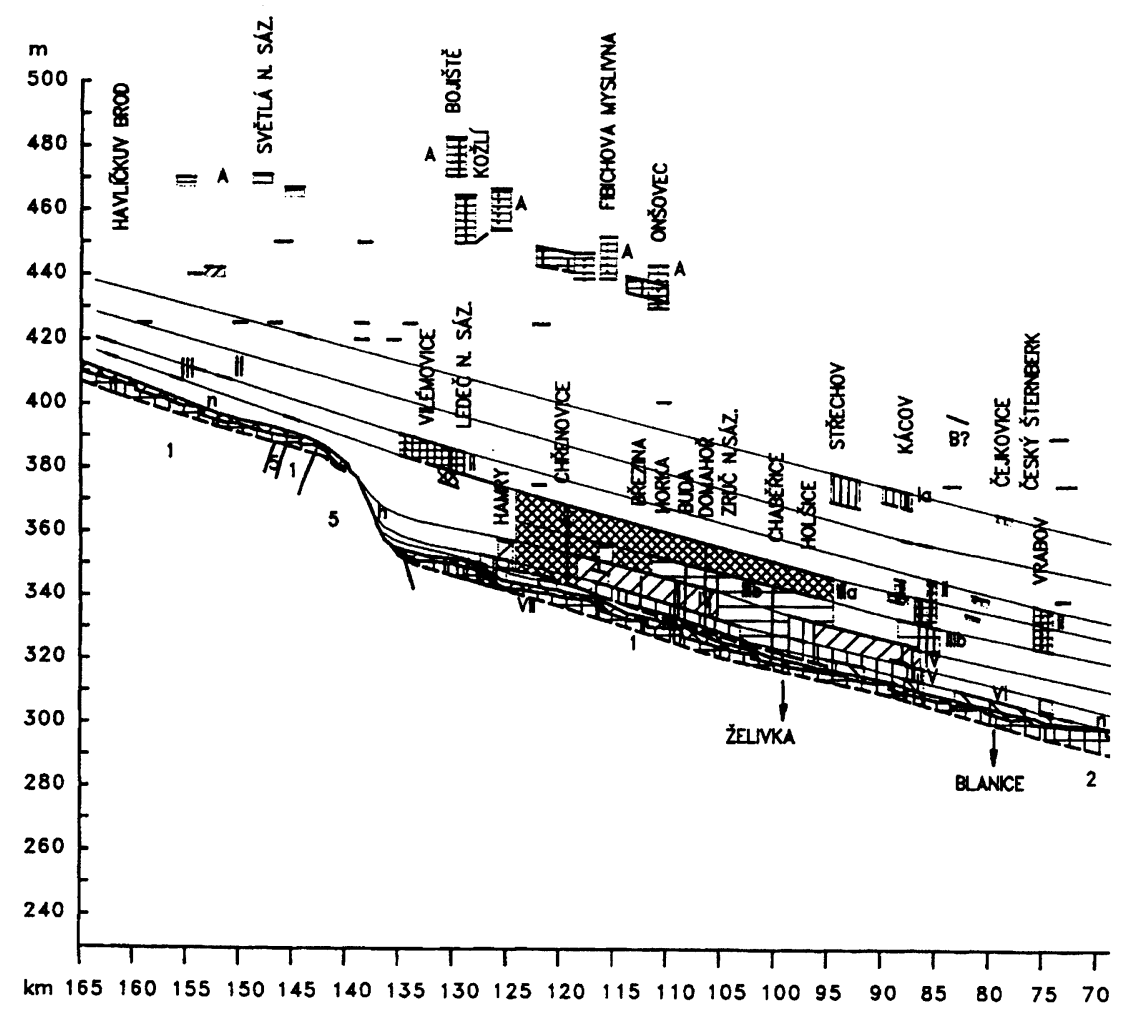

Fig. 5 - The longitudinal profile of the Sázava river terraces between Havlíčkův Brod and Český Śternberk (adapted from Balatka 2007). Explanations: Bedrock (1-6): 1 Moldanubic paragneiss and migmatites, 2-Moldanubic paragneiss with amphibolite body, 3 - metamorphosed volcanites of the Jílové Zone and metamorphosed Upper Proterozoic rocks, inclusive insular zone: rhyolites, dacites, andesites, bazaltes, amphibolite slates and hornstones, 4 - metamorphosed Upper Proterozoic rocks: siltstones, slates and greywackes, 5 - Upper Palaeozoic Plutone: granite, granodiorites, tonalites and diorites, 6 - Ordovician slates, greywackes and sandstones; A, B - Neogene sediments, I-VII - Quaternary terraces ( - - surface, - base $),$ = valley edges, $\mathrm{n}$ - surface of flood plain, $\mathrm{h}$ - river level, I boreholes.

which was accepted by Záruba, Rybár (1961). These models proved the existence of relics of abandoned Pleistocene valley reaches filled by up to $25 \mathrm{~m}$ of terrace sediments in the larger neighbourhood of Zruč nad Sázavou. Today's Sázava valley was probably initiated in the Pliocene as a result of tectonic movements of anticlinal and synclinal character (Moschelesová 1930), which interrupted the original Tertiary drainage of the basin to the north (Novák 1932). If the Lower Miocene Sázava (with Želivka) flowed from the Melechov ridge already westwards, it captured the upper part of the valley to its course probably at the turn of the Miocene and Pliocene. Valley meanders and bends, characteristic for parts of the middle course of the Sázava river, were formed probably as bends on the bottom of the Pliocene wide valley. The present landforms appeared during a phase of Quaternary deepening of the valley, mainly by the development of larger bends with 


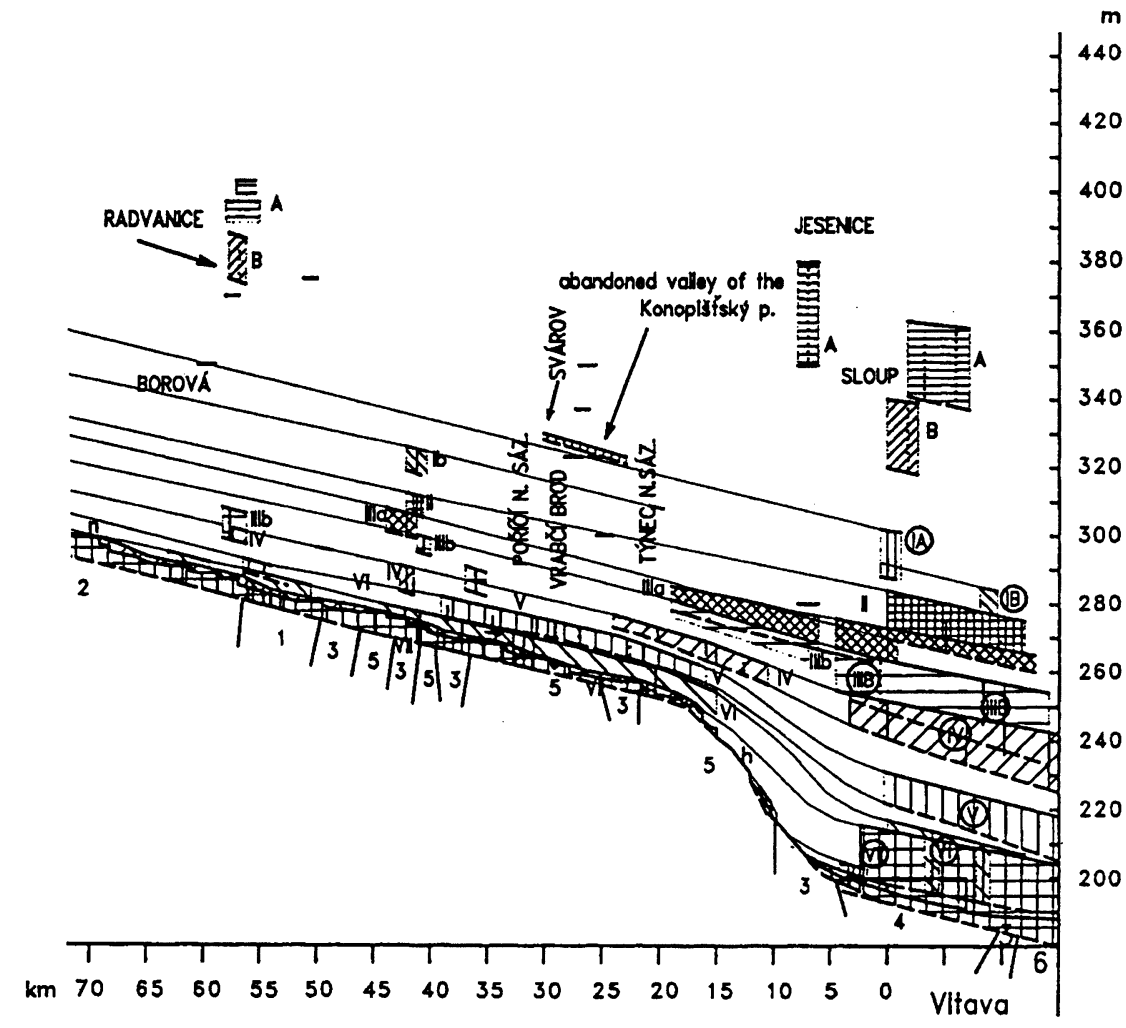

Fig. 6 - The longitudinal profile of the Sázava river terraces between Český Šternberk and the confluence with the Vltava river (adapted from Balatka 2007). For explanations see fig. 5 .

terraces. The valley meanders with a narrow neck, indicate only small shape changes, with the exception of the most exposed extreme parts of concave scarps.

In the Sázava valley, seven main terrace surfaces with several secondary surface levels have been distinguished. The genesis and structure of the terrace system and the valley evolution were influenced by two pronounced incline steps of the river surface - the upper in the middle course and the lower in the lowermost course just before its junction with Vltava River (Balatka 2007). These incline steps caused huge fluvial accumulation in the lower reaches: the lower step mainly in the Vltava River valley, the upper step in the adjacent part of the middle course. Downstream the upper step (in the Melechov granite massif) a huge accumulation (aggradation) of sediments underlying the IIIrd (Chabeřice) terrace was formed (Fig. 5) which, because of its extraordinary thickness of about $25 \mathrm{~m}$, levelled to this incline step.

The Sázava valley includes several remarkable geomorphological characteristics (Balatka, Sládek 1962a; Štěpančíková 2003; Balatka, Štěpančíková 2006; Balatka 2007): a) reaches with closed transverse profiles alternate with wider vales; b) the highest planation plateau surfaces of etchplain and pediplain type are situated mostly at $140-190 \mathrm{~m}$ above the 
river surface. Lower levels of denudational plateaux, generally of smaller dimensions, are situated at relative heights of mostly between 90 and $130 \mathrm{~m}$, and that in two to three height levels situated in the largely open vale valley depression; c) upper edges of canyon-like valley reaches displaying the levels of Quaternary downcutting are situated mostly at 60-85 m (rarely at $40 \mathrm{~m}$ ) above the present river surface.

Relics of Miocene sediments are found in two areas of the planation relief, i.e. in the morphostructural depressions of the Sázava - Želivka interfluve and the Sázava - Labe watershed. They represent relics of accumulation fills of old river channels as well as denudational relics of areal cover. They are fluvial to fluvial-lacustrine sediments, about $10 \mathrm{~m}$ thick, situated above the canyon-like valley cutting, with their surface at $110-135 \mathrm{~m}$ above the river (prevailing level A). Their present occurrences demonstrate either Sázava drainage from the Sázava town to the north (Novák 1932), or, according to Malkovský (1975, 1976; 1979; Ložek et al. 2004), Neogene drainage to the west, i.e. in the direction of the present course. Largely oscillating absolute heights of Neogene localities in the Sázava - Želivka interfluve could indicate their smaller tectonic disturbance reaching about $20 \mathrm{~m}$.

Lower localities situated near the Sázava Town and upstream the confluence with the Blanice situated along the valley cutting belong undoubtedly already to the drainage in the present direction, i.e. to the west. Neogene sediments near Jesenice, southward from Prague, filling deep channels near the Sázava - Vltava watershed (Kovanda et al. 2001) indicate traces of drainage of the lower Sázava catchment to the north. It is indirectly proved also by the prevailing meridional orientations of Sázava tributaries in the larger neighbourhood. A great elevation above the distant Sázava level (over $185 \mathrm{~m}$ ) can be most likely explained by a slight anticline vaulting of the area of the present watershed above the synclinal depression in the localities of the Sázava valley (Moschelesová 1930).

The oldest and highest, mostly Early Pleistocene terraces are maintained only very sporadically in small occurrences, and that above the edges of the valley incision. The relative height of the highest terrace Ia (60 to $105 \mathrm{~m}$ ) indicates the approximate extent of the Quaternary erosion of the Sázava middle and lower course (Fig. 6). The IIIrd terrace group is the most significant set of fluvial landforms in the terrace system of the Sázava River both in occurrence and thickness of sediments. Under the Melechov incline step there occurred huge accumulation of sediments of the IIIrd terrace which, in an unparallel thickness of about $25 \mathrm{~m}$, levelled out this incline step, so that the surface of this terrace was probably continuously aligned parallel to the valley bottom (floodplain) above this step. The erosional stage before the beginning of accumulation of sediments of the IIIrd terrace stopped near the level of the present water surface. It follows from this that the Sázava valley under the Melechov step was deepened already at that time nearly to its present level.

In the valley downstream the Melechov incline step there have formed in the middle course extraordinarily thick accumulations of sediments of the IIIa terrace (Chabeřice Terrace, up to $25 \mathrm{~m}$ ), maintained in their total thickness in shorter abandoned valleys because of channel dislocation during the highest accumulation level (Fig. 5). In alluvia of this Chabeřice Terrace, there was formed a lower erosional terrace IIIb (Buda Terrace, comp. Tab. 1) with its surface about $8 \mathrm{~m}$ lower than the surface of the IIIa terrace and $30 \mathrm{~m}$ above the water level. 
The predominantly sandy deposits of the Chabeřice Terrace indicate the generally constant incline conditions during the terrace sedimentation, with the exception of the beginning of the accumulation, when a higher incline of the channel at the terrace base-level resulted in accumulation of coarser gravels. In a $15 \mathrm{~km}$ long reach under the Melechov incline step, thicker deposits than those of the IIIa terrace were not found, as well as in the nearly $100 \mathrm{~km}$ long reach of the middle and lower course. It is suggested that the surface of the IIIa terrace is bound to the Vltava's Kralupy Terrace (Ib, or IIIA) and its base-level could correspond to the bottom of the Vltava's Karlovo náměstí Terrace - IIIb (Záruba, Rybář 1961). In comparison to the lower Vltava terraces, the sediments of the Chabeřice Terrace (IIIa) are more weathered and thus undoubtedly older.

In the lowermost part of the Sázava course, the IIIrd terrace is maintained above the valley cutting. The surface of the IIIa step is largely divergent downstream from approximately $30 \mathrm{~m}$ at the beginning of the incline step to $75 \mathrm{~m}$ in the Sázava - Vltava confluence area (Fig. 6). The surface of the terrace has a constant gentle inclination and its base-level in the lower course had probably an increased slope that was being progressively levelled out by accumulation progressing from the Vltava valley. Accumulation of sediments filled the furrow in the place of the present valley and during the following erosional stage these sediments were removed. The localities of the IIIrd terrace are represented by sediments from the final accumulation stage when the river widened its valley by lateral erosion to both sides. This is also indicated by minor thickness of sediments at these localities.

The slope steps have significantly influenced valley evolution, i.e. both in the intensity of erosion, depth and the extent of fluvial sedimentation - i.e. the course and position of main terrace elements in the longitudinal profile. While the highest terraces (Ia, Ib, II) represented in the long profile a constant course as incline steps still did not exist, the situation during the

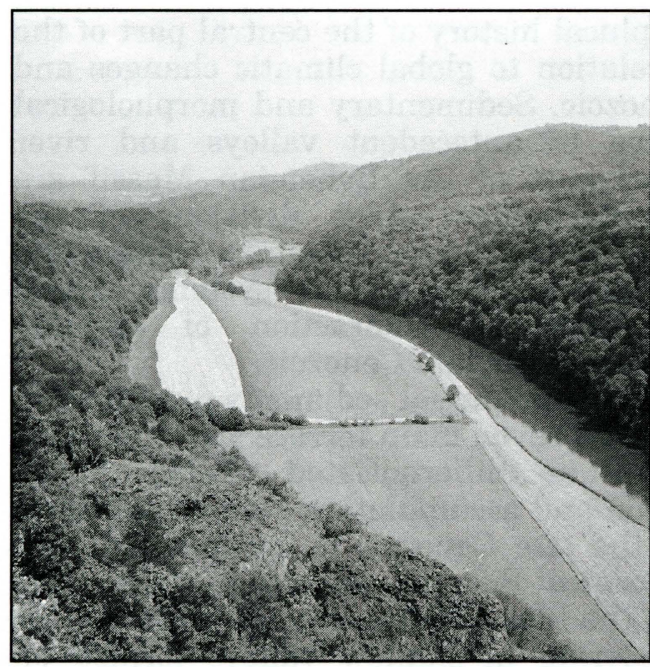

Fig. 7 - Deep valley of the Berounka river with a considerable fluvial plain originated in Cambrian volcanic rocks of the Krrivoklátská vrchovina Highland at the beginning of the Neogene. Photo B. Balatka. formation of the IIIrd terrace was more complex. The highest surface of the IIIrd terrace (IIIa) has also a constant and gentle slope, and the base-level of this terrace in incline steps shows a clear convergence upstream. Similarly, lower terraces, mainly in the lower incline step, show significant convergence upstream, and in the upper incline step the younger terraces are mostly progressively disappearing.

Incline steps of the water level as well as of the valley bottom of the Sázava represent fronts of waves of retrogressive erosion progressing upstream. The lower step was formed an in erosional period between the IVth and the VIIth terrace (Tab. 1), the upper step was essentially formed during the erosional stage between the surface 


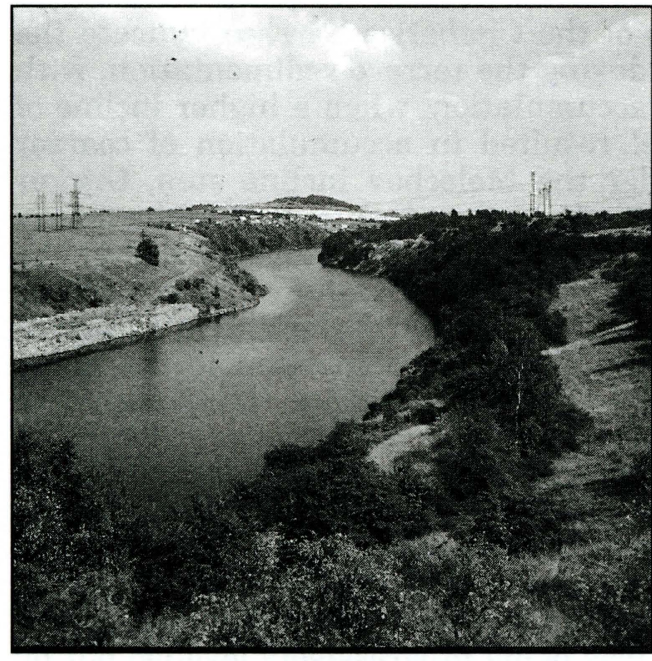

Fig. 8 - Canyon-like valley of the Ohře river in granulitic gneisses of a peripheral region of the Tertiary stratovolcano of the Doupovské hory Mountains is also cut through the complex of Pleistocene fluvial terraces. Photo B. Balatka.

lower Vltava terraces, it is supposed that the corresponding Chabeřice (IIIrd) Terrace is the stratigraphical equivalent to Vltava terraces IIIA (Kralupy) and IIIB (Vinohrady, comp. Tab. 1) which locally form also a uniform accumulation.

\section{Conclusions}

The main features of palaeogeographical history of the central part of the Bohemian Massif are presented in relation to global climatic changes and neotectonic processes during the Cenozoic. Sedimentary and morphological records of the Quaternary evolution of antecedent valleys and river accumulation terraces in the central part of the Bohemian Massif are correlated with regional chronostratigraphical stage divisions of the Quaternary (Table 1). Fluvial sediments in the Vltava, Berounka, Sázava and Labe valleys are preserved as extensive river terrace systems. These accumulation terraces originated from an interaction of climatemorphogenetic and neotectonic processes in the late Cenozoic.

Geomorphological analysis of late Cenozoic fluvial sediments preserved in the Bohemian Massif confirm that in total seven main terrace accumulations with several secondary levels can be differentiated (Table 1). A chronostratigraphical scheme of erosion and accumulation periods and their relations to variable uplift rates in the late Cenozoic is documented. The oldest river terrace accumulations in central Bohemia are situated above the margins of the canyon-like valleys. In the Early Pleistocene, the Vltava river and its affluents were freely meandering in shallow valleys formed on Neogene planation surfaces. The relative height of the oldest fluvial terraces above the present-day bottom of river valleys in the central part of the Bohemian Massif is more than $100 \mathrm{~m}$ which indicates the approximate depth of erosion in the Quaternary. An estimation of the values of the antecedent 
deepening of the Vltava in the late Cenozoic according to the position of relics of river accumulation terraces suggests that the rate of downward erosion of the Vltava probably reached its maximum of between 6 and $10 \mathrm{~cm} / 100$ years in part of the Middle Pleistocene.

Analysis of sediment transfers in the Quaternery environment was concentrated on fluvial transport and sedimentation in relation to neotectonics and climate changes in the Bohemian Massif. Important changes in the fluvial network occurred with significant manifestations of epigenetic and antecedent evolution of river valleys through deep, lateral and headward erosion. These processes were also connected with reconstruction of the large area of sedimentation of transported material. It is suggested to study the dynamics of fluvial processes together with records about weathering, denudation, erosion and mass movements.

\section{References:}

BALATKA, B. (1992): Terrace systems of rivers in the Bohemian Upland and the Czechoslovak Carpatians and their comparison. Analysis and Synthesis of Geographic Systems. Institute of Geography of the Czechoslovak Academy of Sciences, Brno, pp. 113-137.

BALATKA, B. (2006): Podrobné členění reliéfu Čech. Detailed regionalization of the relief of Bohemia. In: Balatka, B., Kalvoda, J. (eds.): Geomorfologické členění reliéfu Čech. Kartografia a.s., Praha, 79 p., suppl. pp. 18-22.

BALATKA, B. (2007): River terraces and the Sázava Valley evolution. In: Goudie, A. S., Kalvoda, J. (eds.): Geomorphological variations. P3K Publ., Prague, pp. 361-386.

BALATKA, B. et al. (1973): Regionální členění reliéfu ČR. Sborník ČSZ, 78, No. 2, pp. 81-96.

BALATKA, B., KALVODA, J. (1995): Vývoj údolí Labe v Děčínské vrchovině. Sborník ČGS, 100 , č. 3 , pp. 173-192.

BALATKA, B., KALVODA, J. (eds., 2006): Geomorfologické členění reliéfu Čech. Geomorphological regionalization of the relief of Bohemia. Kartografia a.s., Praha, 79 p.

BALATKA, B., LOUČKOVÁ, J. (1992): Terasový systém a vývoj údolí Berounky. Studia geographica, 96, Brno, 53 p.

BALATKA, B., SLÁDEK, J. (1962a): Říční terasy v českých zemích. Geofond v NČSAV, Praha, $580 \mathrm{p}$.

BALATKA, B., SLÁDEK, J. (1962b): Terasový systém Vltavy a Labe mezi Kralupy a Českým středohořím. Rozpravy Československé akademie věd. Řada matem.-př́r. V., 72, No. 11, Praha, 62 p.

BALATKA, B., ŠTĚPANĆKKOVÁ, P. (2006): Terrace system of the middle and lower Sázava River. Geomorphologia Slovaca, 6, No. 1, Bratislava, pp. 69-81.

BUDAY, T. et al. (1961): Tektonický vývoj Československa. Academia, Ústřední ústav geologický, Praha, $250 \mathrm{p}$.

CZUDEK, T. (1997): Reliéf Moravy a Slezska v kvartéru. Sursum, Tišnov, 213 p.

DANEŠ, J. V. (1913): Morfologický vývoj středních Čech. Sborník CSZ, 18, Praha, pp. 1-18, 94-108 and 168-176.

DEMEK, J. (2004): Etchplain, rock pediments and morphostructural analysis of the Bohemian Massif (Czech Republic). In: Drbohlav, D., Kalvoda, J., Voženílek, V (eds.): Czech Geography at the Dawn of the Millenium. Czech Geographical Society, Palacky University in Olomouc, Olomouc, pp. 69-81.

DEMEK, J. et al. (1965): Geomorfologie Českých zemí. Nakladatelství ČSAV, Praha, 335 p.

EISSMANN, L. (1975): Das Quartär der Leipziger Tieflandschaftbucht und angrenzenden Gebiete um Saale und Elbe. Schriftenreihe für geologische Wissenschaften, Heft 2, Berlin, $263 \mathrm{p}$.

EISSMANN, L. (1995): VIII. Sachsen. In: Benda, L. (ed.): Das Quartär Deutschlands. Gebrüder Borntraeger, Berlin, Stuttgart, pp. 171-198.

EISSMANN, L. (1997): Das quartäre Eiszeitalter in Sachsen und Nordtüringen. Altenburger Naturwissenschaften Forschungen, 8, pp. 1-98. 
ENGEL, Z., KALVODA, J. (2002): Morphostructural development of the sandstone relief in the Bohemian Cretaceous Basin. In: Přikryl, R., Viles, H. (eds.): Understanding and Managing stone decay. SWAPNET, Karolinum Press, Praha, pp. 225-231.

GIBBARD, P., BOREHAM, S., COHEN, K. M., MOSCARIELLO, A. (2004): Global chronostratigraphical correlation table for the last 2.7 million years. Quaternary Palaeoenvironment Group, University of Cambridge, Cambridge, 2 p., 1 plate.

CHLUPÁČ, I. et al. (2002): Geologická minulost České republiky. Academia, Praha, 436 p.

IVAN, A. (1999): Geomorphological aspects of late Saxonian epiplatform orogeny of the Bohemian Massif. Moravian Geographical Reports, 7, No. 1, Brno, pp. 18-33 and No. 2, pp. 12-31.

KALVODA, J. (2007a): Morphostructural evolution of the relief in the locality of the Geodynamic Observatory at Pecný, the Ondřejovská vrchovina Highland, Czech Republic. In: Goudie, A. S., Kalvoda, J. (eds.): Geomorphological variations. P3K Publ., Prague, pp. 387-407.

KALVODA, J. (2007b): Rapid fluvial processes in the Late Quaternary. In: Langhammer, J. (ed.): Změny v krajině a povodňové riziko. Sborník příspěvků semináře "Povodně a změny v krajině", Přírodovědecká fakulta Univerzity Karlovy v Praze, Praha, pp. 17-28.

KALVODA, J., BALATKA, B. (1995): Chronodynamics of the Labe River Antecendence In the Děčínská vrchovina Highland. Acta Montana, Ser. A, 8 (97), Praha, pp. 43-60.

KALVODA, J., BALATKA, B. (2006): Morfostrukturní vývoj reliéfu české části Českého masivu. Morphostructural evolution of the relief of the Bohemian part of the Český masiv Massif. In: Balatka, B., Kalvoda, J. (eds.): Geomorfologické členění reliéfu Čech. Kartografia a.s., Praha, pp. 5-12.

KALVODA, J., KOSTELECKÝ, J. (jr.), KOSTELECKÝ, J. (2004): A pilot morphotectonic interpretation of position changes of the permanent GPS stations in Central Europe. In: Drbohlav, D., Kalvoda, J., Voženílek, V. (eds.): Czech Geography at the Dawn of the Millenium. Czech Geographical Society, Palacky University in Olomouc, Olomouc, pp. 113-123.

KOVANDA, J. et al. (2001): Neživá příroda Prahy a jejího okolí. Academia, Český Geologický Úřad, Praha, 215 p.

KREJČÍ J. (1939): Profil rovnováhy jakožto základ studie říčních teras. Spisy Odborné České Společnosti zeměpisné v Brně, 5 , Brno, 144 p.

LOŽEK, V., ŽÁK, K., CÍLEK, V. (2004): Z minulosti českých řek. Vesmír, 83, č. 1, Praha, pp. $447-453$.

MALKKOVSKÝ, M. (1975): Palaeogeography of the Miocene of the Bohemian Massif. Věstník Ústředního Ústavu geologického, 50, No. 1, Praha, pp. 27-31.

MALKOVSKÝ, M. (1976): Saxonische Tektonik der Böhmische Masse. Geologische Rundschau, 65, Stuttgart, pp. 127-143.

MALKOVSKÝ, M. (1979): Tektogeneze platformního pokryvu Českého masívu. Ústřední Ústav geologický v Academii, Praha, $176 \mathrm{p}$.

MALKOVSKÝ, M. et al, (1985): Geologie severočeské hnědouhelné pánve a jejího okolí. Academia, Ústřední Ústav geologický, Praha, 424 p.

MOSCHELESOVÁ, J. (1930): Vlnité prohyby o velké amplitudě v jižních Čechách. Sborník ČSZ, 36, Praha, pp. 155-158.

NOVÁK, V. J. (1932): Vývoj úvodí a údolí řeky Sázavy. Věstník Královské České společnosti nauk, 11 , Praha, $47 \mathrm{p}$.

ŠTĚPANČ́́KKOVÁ, P. (2003): Terasy dolní Sázavy v úseku od Vrabčího Brodu po Kamenný Přívoz. Geografie-Sborník ČGS, 108, č. 3, Praha, pp. 216-226.

TYRÁČEK, J. (2001): Upper Cenozoic fluvial history in the Bohemian Massif. Quaternary International, 79, London, pp. 37-53.

TYRÁČEK, J., WESTAWAY, R., BRIDGLAND, D. (2004): River Terraces of the Vltava and Labe (Elbe) system, Czech Republic, and their implications for the uplift history of the Bohemian Massif. Proceedings of the Geologists'Association, 115, London, pp. 101-124.

WAGNER, G. A., GÖGEN, K., JONCKHEERE, R., KÄMPF, H., WAGNER, I., WODA, C. (1998): The age of Quaternary volcanoes Železná hůrka and Komorní hůrka (western Eger Rift), Czech Republic: alpha-recoil track, TL, ESR and fission track chronometry. Excursion guide and Abstracts of Workshop, Intern. Geol. Correl. Progr. No. 369 „Magmatism and Rift Basin Evolution“, 7.9.-11.9.1998, Liblice, Czech Geological Survey, Prague, pp. 95-96.

WOLF, L. (1980): Die elster- und präelsterkaltzeitlichen Terrassen der Elbe. Zeitschrift für geologische Wissenschaften, 8, Heft 10, Berlin, pp. 1267-1280. 
WOLF, L., SCHUBERT, G. (1992): Die spättertiären bis elstereiszeitlichen Terrasen der Elbe und ihrer Nebenflüsse und die Gliederung der Elster-Kaltzeit in Sachsen. Geoprosil, 4, 43 p.

ZÁRUBA-PFEFFERMANN, Q. (1941): Původ štěrků z terasy u Lysolaj a Suchdola. Zprávy Geologického Ústavu pro Cechy a Moravu, 17, Praha, pp. 298-308.

ZÁRUBA-PFEFFERMANN, Q. (1942): Podélný profil vltavskými terasami mezi Kamýkem a Veltrusy. Rozpravy II. třídy České Akademie, 52, č. 9, Praha, 39 p.

ZÁRUBA, Q., RYBÁ ̌́, J. (1961): Doklady pleistocenní agradace údolí Sázavy. Sborník ČSZ, 66 , č. 1, Praha, pp. 23-30.

ZÁRUBA, Q., BUCHA, V., LOŽEK, V. (1977): Significance of the Vltava Terrace system for Quaternary chronostratigraphy. Rozpravy Československé akademie věd, Řada matem.př́r. V., 87, No. 4, Academia, Praha, 90 p.

ZEMAN, A. (1974): Současný stav výzkumu pleistocénních fluviálních sedimentů v Dyjskosvrateckém úvalu a jejich problematika. Studia geographica, 36, Geografický ústav ČSAV, Praha, pp. 41-62.

\section{Shrnutí}

\section{VÝVOJ KVARTÉRNÍCH ŘÍČNÍCH AKUMULAČNÍCH TERAS VE VZTAHU KE ZDVI- HU CENTRÁLNÍ Č́STI ČESKÉHO MASIVU}

Paleogeografická historie centrální části Českého masivu je popsána zejména s ohledem na globální klimatické změny a neotektonické procesy v kenozoiku. Sedimentární a morfologický záznam vývoje antecedentních údolí a ř́íních akumulačních teras je porovnán se stratigrafickými stadii kvartéru v Evropě. Fluviální sedimenty v údolích Vltavy, Berounky, Sázavy a Labe jsou zachovány jako rozsáhlý systém říčních teras. Tyto akumulační terasy vznikaly interakcí klimato-morfogenetických a netektonických procesů v mladším kenozoi$\mathrm{ku}$.

Geomorfologická analýza fluviálních sedimentů mladšího kenozoika potvrdila, že lze rozlišovat sedm hlavních terasových akumulací s několika sekundárními úrovněmi (tab. 1). Je navrženo chronostratigrafické schema erozních a akumulačních období a jejich vztahů k variabilním hodnotám zdvihu v mladším kenozoiku.

Nejstarší ŕíční akumulační terasy ve středních Čechách jsou umístěny nad okraji kaňonovitých údolí. V nejstarším pleistocénu Vltava a její přítoky volně meandrovaly v mělkých a širokých údolích na zarovnaném povrchu neogenního stáří. Relativní výška nejstarších říčních teras nad současným dnem ř́ičních údolí centrální části Českého masivu je více než $100 \mathrm{~m}$, což indikuje přibližný rozsah hloubkové eroze řek během kvartéru. Geomorfologická stanovení hodnot antecedentního zahlubování Vltavy $\mathrm{v}$ mladším kenozoiku, zejména podle polohy a sedimentární struktury reliktů říčních akumulačních teras, svědčí o tom, že hloubková eroze této řeky byla nejvyšší v části středního pleistocénu, a to mezi $6-10 \mathrm{~cm} \mathrm{za}$ 100 let.

Analýza dynamiky přemístování sedimentů v kvartérním přírodním prostředí byla zaměřena na fluviální transport a sedimentaci ve vztahu k neotektonice a klimatickým změnám v Českém masivu. Byly prokázány podstatné změny charakteru řiční sítě s postupným epigenetickým a antecedentním vývojem údolí. Tyto kvartérní procesy jsou zároveň spojeny s rekonstrukcí rozsáhlých oblastí sedimentace řekami transportovaného materiálu. Je zdůrazněno, že komplexní výzkum dynamiky fluviálních procesů vyžaduje také studium procesů zvětrávání, denudace, eroze a svahových pohybů.

Obr. 1 - Neovulkanická kupa Říp (461 m) z vypreparované nefelinitové diatremy je obklopena kvartérním systémem říčních akumulačních teras širší oblasti soutoku Labe a Vltavy. Foto B. Balatka.

Obr. 2 - Antecedentní údolí Labe u Litoměřic vyhloubené do krystalinické hrásti vyzdviženého podloží neovulkanitů Českého středohoří. Foto B. Balatka.

Obr. 3 - Poloha ř́ičních akumulačních teras v údolí Vltavy mezi jejími soutoky se Sázavou a Berounkou. Upraveno podle Balatky, Štěpančíkové (2006) a Balatky (2007).

Obr. 4 - Příčný profil pleistocenní suchdolskou říční akumulační terasou Vltavy u Únětic. Upraveno podle Záruby a kol. (1977) a Tyráčka a kol. (2004). Vysvětlivky: K - proterozoické lydity, 1 - štěrky suchdolské terasy, 2 - nivní jíly, 3 - vápnité říční sedimenty, 4 - hnědá odvápněná nivní půda, 5 - šedý sladkovodní slín, 6 - vrstva 
tmavé humózní glejové půdy, 7 - vrstva rezavě hnědé glejové půdy, 8 - proluviální sedimenty se zvětralých kř́ídových písčitých vápenců, 9 - jílovité proluvium, 10 - zvětralé vápnité tufy, 11 - proluvium s drtěmi kř́dových hornin, 12 - svahové drtě z proterozoických lyditů, 13 - spraš, 14 - parahnědozemní půda, 15 - alterovaná černozem, 16 - postglaciální černozem, 17 - pravděpodobné magnetostratigrafické rozhraní mezi chrony Matuayama a Brunhes (podle interpretace Záruby et al. 1977).

Obr. 5 - Podélný profil říčními terasami Sázavy mezi Havlíčkovým Brodem a Českým Šternberkem. Upraveno podle Balatky (2007). Vysvětlivky: skalní podloží (1-6): moldanubické pararuly a migmatity, 2 - moldanubické pararuly s amfibolitovým tělesem, 3 - metamorfované vulkanity jílovského pásma a metamorfované svrchnoproterozoické horniny včetně ostrovní zóny: ryolity, dacity, andezity, amfibolické břidlice a rohovce, 4 - metamorfované svrchnoproterozoické horniny: prachovce, břidlice a droby, 5 - svrchnopaleozoický pluton: granity, granodiority, tonality a diority, 6 - ordovické břidlice, droby a pískovce; A, B - neogenní sedimenty, I-VII - kvartérní terasy (- - povrch, - báze), = erozní hrany údolí, n - povrch říćní nivy, h - hladina řeky, I - vrty.

Obr. 6 - Podélný profil říčními terasami Sázavy mezi Českým Šternberkem a jejím ústím do Vltavy. Upraveno podle Balatky (2007). Vysvětlivky viz obr. 5.

Obr. 7 - Hluboké údolí Berounky s výraznou říční nivou, vytvořené v kambrických vulkanitech Křívoklátské vrchoviny, bylo založeno již na počátku neogénu. Foto $\mathrm{B}$. Balatka.

Obr. 8 - Kaňonovité údolí Ohře v granulitových rulách periferní oblasti terciérního stratovulkánu Doupovských hor je vyhloubeno také do plošin staropleistocenních říčních teras. Foto B. Balatka.

Authors are with Charles University in Prague, Faculty of Science, Department of Phisical Geography and Geoecology, Albertov 6, 128 43, Praha 2, Czechia; e-mail:

kalvoda@natur.cuni.cz. 